\title{
Review Paper: Crisis Management at Iranian Schools: A Review Study
}

Seyed Nouredin Hosseinighousheh ${ }^{1}$, Alireza Khammar ${ }^{2}$ (D), Shiva Hosseini Foladi ${ }^{3}$, Reyhaneh Ivanbagha ${ }^{4}$, Mir Hossein Ahagh $^{5}$, Razieh Veisi', Mahsa Hami ${ }^{7}$, Mohsen Poursadeqiyan ${ }^{8,9 *}$ (D)

1. Social Determination of Health Sciences, Yasuj University of Medical Sciences, Yasuj, Iran.

2. Zabol Medicinal Plants Research Center, Department of Occupational Health, Zabol University of Medical Sciences, Zabol, Iran

3. Department of Health Services Management, Student Research Committee, Isfahan University of Medical Sciences, Isfahan, Iran.

4. Department of Midwife, Nursing School, Khalkhal University Medical Sciences, Khalkhal, Iran.

5. Department of Public Health, Khalkhal University Of Medical Sciences, Khalkhal, Iran.

6. Research Center for Environmental Determinants of Health (RCEDH), Health Institute, Kermanshah University of Medical Sciences, Kermanshah, Iran

7. Health Management and Economics Research Center, Iran University of Medical Sciences, Tehran, Iran.

8. Department of Occupational Health Engineering, Torbat Heydariyeh University of Medical Sciences, Torbat Heydariyeh, Iran.

9. Health Sciences Research Center, Torbat Heydariyeh University of Medical Sciences, Torbat Heydariyeh, Iran.

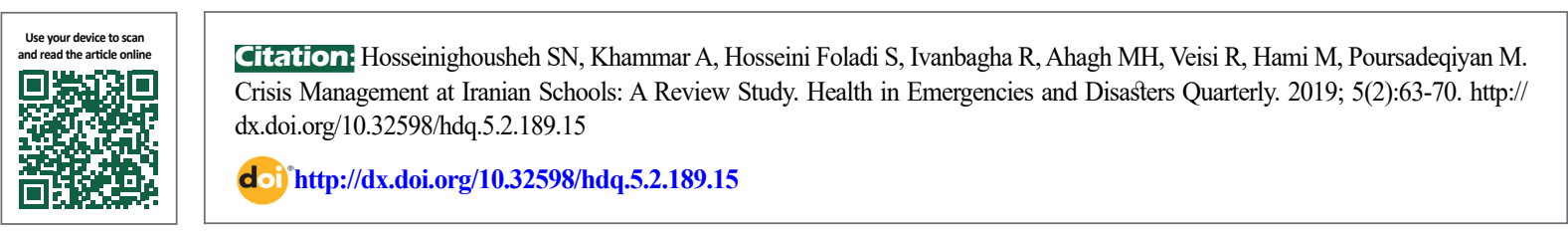

(c) (1) (5)

Article info:

Received: 09 Nov 2018

Accepted: 22 Jun 2019

Available Online: 01 Jan 2020

Keywords:

Crisis management, Crisis, School, Disaster, Iran

\section{ABSTRACT}

Background: Occurring natural crises and lack of meticulous planning for confronting their damages and casualties can result in losing human and material resources. Moreover, it should be considered that crisis management is a kind of management in which prevention, intervention, and confrontation with the crisis are very important because these measures can decrease the detrimental impact of crises, especially at schools by saving students' lives. Therefore, regarding the importance of the subject, this study aimed to review studies on crisis management at Iranian schools.

Materials and Methods: The study took place by a systematic search using Persian and English keywords on databases like Google Scholar, SID, and Magiran to find relevant research studies conducted in Iran until October 2018. Furthermore, the lists of references were checked to find more relevant studies. Out of 575 articles, the full texts of 12 studies were considered and the results of the searching were examined independently based on inclusion and exclusion criteria by two researchers after dismissing duplicates. Finally, 4 studies were qualified to be included in this review.

Results: All studies used some questionnaires for assessing the outcomes. The target population consisted of students, teachers, principals, and experts of crisis management. Among the examined articles, two studies were about earthquake crisis management, and the other two discussed crisis management at schools. The level of preparedness for confrontation with the crisis, the effectiveness of crisis management course, dimensions and components of crisis management, and the priority of effective factors for readiness to confront crises were reported in the studies.

Conclusion: Findings showed that students, teachers, and principals should receive necessary training about crisis management for preventing any probable injuries to children while confronting the crisis at schools. Consequently, it is suggested that the officials take crisis management at schools into serious consideration.

\section{* Corresponding Author:}

Mohsen Poursadeqiyan, PhD

Address: Health Sciences Research Center, Torbat Heydariyeh University of Medical Sciences, Torbat Heydariyeh, Iran

E-mail: mo.poursadeghiyan@uswrac.ir 


\section{Introduction}

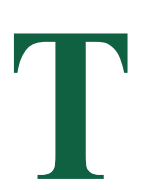

he natural crises influence the lives of millions of people in the world which lead to the enormous economic and social costs and weaken the development of countries. Despite attempts made in most countries for reducing the risk and negative impacts of crises, damages and costs of most crises are increasing [1]. The consequences of natural and man-made disasters may result in human casualties, financial, and social losses. By affecting societies, crises disrupt the everyday life of people and waste considerable resources for returning to the natural state [2]. Crisis reduces health level and quality of life so that the most important attempts of humans for confrontation are planning before the crisis and implementing the plan during and after the crisis which decreases problems arising from a crisis [3]. The lack of readiness and improper confrontation with natural crises have caused heavy damages to nations and their assets which are sometimes irretrievable. Therefore, the management of natural disasters can decrease costs and secure societies against them [4].

So that in recent decades, the science of crisis management has been put forward as the knowledge of prevention, preparedness, and confrontation with crises that threaten human societies. In recent years, this science has gained serious popularity among students of both theoretical and practical fields [5]. Crisis management consists of five categories of organization, communications, decision-making, recognition of crisis factors, and planning. Crisis control is easier when the organization of counteracting forces is effective [6]. School is the first society in which a child steps in and if the school provides some skills based on education, it will improve the life skills of children. Children and young adults live, learn, and bring up in schools for 12 years. They gain the first social life experiences in the school and many of their conceptions, presuppositions, beliefs, and feedbacks to life are evaluated and experienced at school and in class [7].

One of the most important groups that are in danger of accidents and disasters are students as almost half of the country's population is children and young adults. The Japan International Cooperation Agency asserted that disasters have serious impacts on the educational services; the impacts are not only because of the death of teachers and students but also mostly due to the sudden pause in the course of education and students' psychological disorders [8]. The experiences gained from the crises in Iran and all over the world have shown that although organizations, relief administrations, and non-governmental institutions have enough and necessary readiness for action in the scenes of accidents, they suffer from weakness and disability for different reasons in confrontation with disasters [9].

Therefore, states should prepare plans for prevention, confrontation, and control of the various kinds of crises at national, regional, provincial, and local levels. By having a comprehensive program for crisis management, principals are continuously ready for a confrontation with crises in schools, and in addition to prevention, they reduce the impact of crises and save the schools from the whirlpool of various crises and consequently the least possible damages [10].

However, the main part of the damages and losses results from the unfamiliarity with safety regulations, ignorance of conditions and unsafe locations, and disability to use safety tools. The major reason for all of that lies in the method of training in this area. Undoubtedly, for changes in knowledge and skills, at first, we should change attitudes toward the dangers which intimidate humans and provide suitable opportunities for culture-making and operational exploitation in the future. Thus the best and most suitable target society for the change and development of educational methods and attitudes toward safety issues are children and primary school students.

Naturally, adequate preparation of this important target group by using practical, new, and effective instructional methods and tools can present a safe future for our country, because the students keep in mind perpetually whatever they learn and transfer them to their families, too [11]. So regarding the dangerous geographical location of Iran and the importance of the safety of students in the educational environment, this review study was conducted for studying crisis management at schools.

\section{Materials and Methods}

The study took place by a systematic search using Persian and English keywords in databases like Google Scholar, SID, and Magiran to find relevant research studies conducted in Iran until October 2018. Furthermore, the lists of references were checked to find more studies. Keywords were "crisis management", "school", and "crisis". The studies were selected which were published in English or Persian about crises and Iranian schools. The studies with un-related results and ones without enough data for analysis were excluded, too. Finally, after removing the duplicates, the results of the searching were examined by two independent researchers based on 


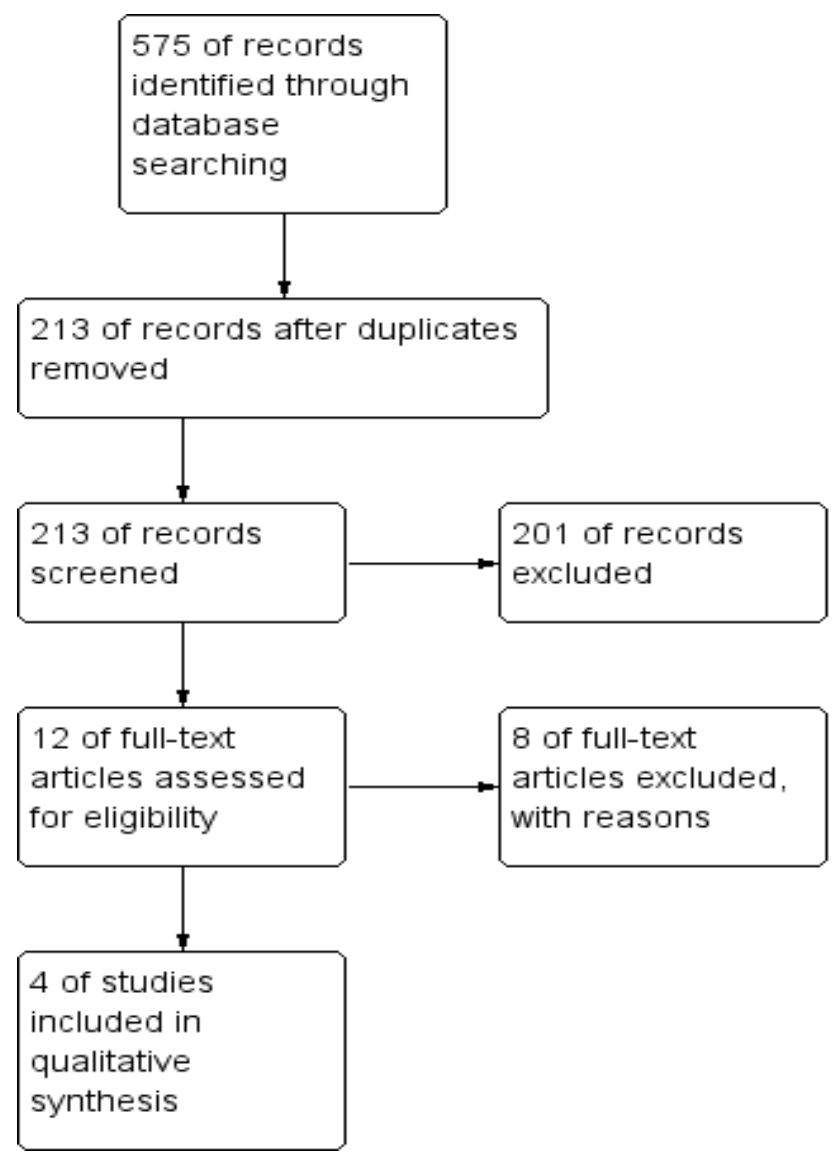

Emergencies and D]isasters [Oluarterly

Figure 1. Flow chart of the identifying and retrieving process of studies

the inclusion and exclusion criteria, and the data of the final phase of analysis was extracted and interpreted.

\section{Characteristics of studies}

Figure 1 shows the flow chart of the identifying and retrieving process of data. Out of 575 articles, the full texts of 12 were assessed and finally, 4 studies were qualified to be included in the final analysis. Three studies examined the target population of teachers and principals and one study considered students as target study. In all studies, a questionnaire was used for evaluating the outcome. The characteristics of the included data were presented in Table 1.

\section{Results}

Pourahmadi et al. (2014) evaluated the effectiveness of crisis management in raising the scientific knowledge of students and assessed the education system deficiencies. A total of 180 guidance school students (135 boys, 45 girls) were selected from 20 schools of Isfahan and included in the study [12]. They were trained for the earthquake crisis in 6 sessions. The data collection tool was a questionnaire. At the end of the study, $87.22 \%$ of the students asserted that the crisis management course mostly achieved the assigned educational aims. The results of the study showed that if educational programs of crisis management at schools are accompanied by necessary continuation and dynamism as well as family care, support, and encouragement, significant changes will take place at the students' awareness level, information and performance at the time of the earthquake [10].

The study of Shirzad Kebria (2013) was conducted to identify the aspects and main components of crisis and to suggest a good strategy at high schools of Tehran. The research statistical population was all high school principals that finally, 170 of them were chosen. The study data were collected through a 48-item researcher-made questionnaire. The internal school components including physical, prevention, and interventional aspects were desirable and sub-components of education and services of health were very poor. Internal school components influenced external ones except for the education and services of the health aspect in which the influence was not seen [10]. 
Table 1. The characteristics of the included studies

\begin{tabular}{|c|c|c|c|c|c|c|c|}
\hline Crisis & Study Tools & $\begin{array}{l}\text { Study } \\
\text { Design }\end{array}$ & Sample Size & City & $\begin{array}{l}\text { The Study } \\
\text { Population }\end{array}$ & Year & Author \\
\hline Earthquake & Questionnaire & $\begin{array}{l}\text { Interven- } \\
\text { tional }\end{array}$ & 180 & $\begin{array}{l}\text { Isfa- } \\
\text { han }\end{array}$ & Students & 2014 & Pourahmadi [12] \\
\hline $\begin{array}{l}\text { School crisis: A) internal } \\
\text { school factors: physical } \\
\text { aspect, prevention as- } \\
\text { pect, intervention aspect, } \\
\text { education and services of } \\
\text { the health aspect } \\
\text { B) external school factors }\end{array}$ & $\begin{array}{l}\text { Researcher-made } \\
\text { questionnaire }\end{array}$ & $\begin{array}{l}\text { Descrip- } \\
\text { tive-ana- } \\
\text { lytic }\end{array}$ & 170 & Tehran & $\begin{array}{l}\text { School } \\
\text { principals }\end{array}$ & 2013 & $\begin{array}{c}\text { Shirzad Kebria } \\
{[10]}\end{array}$ \\
\hline School crisis & $\begin{array}{l}\text { Delphi question- } \\
\text { naire, pair question- } \\
\text { naire, FAHP ques- } \\
\text { tionnaire, Topsis } \\
\text { questionnaire and } \\
\text { library resources }\end{array}$ & $\begin{array}{l}\text { Survey- } \\
\text { analytic }\end{array}$ & Not reported & $\begin{array}{l}\text { Ma- } \\
\text { shad }\end{array}$ & $\begin{array}{l}\text { School prin- } \\
\text { cipals and } \\
\text { teachers }\end{array}$ & 2016 & $\begin{array}{c}\text { Nezhad Shokoohi } \\
\text { [13] }\end{array}$ \\
\hline Earthquake & $\begin{array}{l}\text { Analysis of hierar- } \\
\text { chal process (AHP) } \\
\text { and schools readi- } \\
\text { ness questionnaires }\end{array}$ & $\begin{array}{l}\text { Descrip- } \\
\text { tive-survey }\end{array}$ & $\begin{array}{l}\text { Managers: } 110 \\
\text { Experts: } 20\end{array}$ & Shiraz & $\begin{array}{l}\text { School } \\
\text { principals } \\
\text { and crisis } \\
\text { experts }\end{array}$ & 2016 & $\begin{array}{l}\text { Mehraeen Naz- } \\
\quad \text { dik [3] }\end{array}$ \\
\hline
\end{tabular}

The research of Shokouhi et al. (2016) was performed through the fuzzy analytic hierarchy process (FAHP) method to identify and prioritize the factors which affect the readiness for confrontation with the natural disasters at schools. In this research, firstly criteria and sub-criteria of the readiness for confrontation with crises were obtained by using the Delphi technique and regarding the experts' ideas. Then, the related criteria and sub-criteria were ranked through the phase AHP technique. At first, 10 questionnaires were given to the experts for identifying the indexes of preparedness for the crisis at schools. The experts were the active principals and teachers who were involved in the crisis at schools. Afterward, the obtained indexes and their sub-criteria were given to the school principals who were aware of crisis so that they ranked them through the FAHP method [13].

The results showed that the most effective factors of preparedness for confrontation with the crisis in schools were safety measures, consideration of primary standards, committee making, relationship with institutions and organizations that are relevant to crisis management, regular inspection, and training. So it appeared that safety measures have a crucial role in preparedness. According to the results of the FAHP, the most important subcriterion of safety measures is the safety of the building, and consideration of primary standards is making the earthquake-proof school building. Regarding the committee making, establishing a crisis council at schools and health council and regarding regular inspection, the regular checking of the safety state of classes were very important. In training, the most important sub-criteria were the introduction of safe places, the way of suitable shelter seeking, the introduction of emergency exit routes, and training of the way of exit [13].

The research of Mehraeen Nazdik et al. (2016) was done to assess the preparedness of the high schools of Shiraz for confrontation with the earthquake crisis. This study used two questionnaires of analysis of the hierarchal process (AHP) and school readiness questionnaire. AHP assessed the preparedness of schools in three dimensions of emergency programs, emergency operations, and emergency sources. The second questionnaire analyzed the readiness of schools for confrontation with the earthquake risk through 36 questions. Findings showed that the emergency programs have the most and the emergency operations have the least importance among the dimensions of readiness. Moreover, among the schools, $6.9 \%$ had very high readiness, $32.7 \%$ high readiness, $29.7 \%$ average readiness, $22.8 \%$ low readiness, and $7.9 \%$ very low readiness to confront the earthquake risk. The study showed that the readiness rate of the primary high schools of Shiraz is lower than the desirable level [3].

Borzoueekhah (2018) also examined the attitude change of the primary school students of Qom to the safety and crisis management issues at the Education Center of Ready Children at school. They considered children and the primary school students as the best and most suitable 
Table 2. Suggestions concerning crisis management

Studies
Suggestions
1. Doing monthly earthquake maneuvers at schools
2. Creating active and continuous awareness among the students and educators
3. Making visiting camps and developing practical courses for students' parents and their children
4. Selecting active schools principals in crisis management as the model principals
5. Educational plans in the form of posters, placards, films, discussions, and competitions
1. Examining factors creating internal and external school crises
2. Compiling regulations of crisis management specific to each school
3. Strengthening the educational advisors team at high schools
4. Strengthening the health team (health educator, doctor) at high schools
5. Planning a comprehensive strategy for using a mediation program to solve the student crisis
6. Considering the system and physical space at high schools
7. Inserting crisis solving skill (through avoiding crisis) into the curriculum in an applied form for high school
students
8. Strengthening the crisis team in partnership with principal, teacher, students, parents and local community
members for a timely intervention at the necessary times
9. Strengthening the crisis team at school to present relevant information to the students about the new crises

Shokouhi Emphasizing schools safety measures and building schools based on the world latest standards

Mehraeen Nazdik Adding some educational centers and compulsory courses for the school staff and students at close intervals along with awarding certificate and identification card

Borzoueekhah

Foomani and colleagues
Training children and the primary school students about safety issues by using effective, practical, and updated methods and tools
Mostafavi Darani and colleagues
Describing the role of training in promoting the knowledge and attitudes of the primary schools' principals in the establishment of safety, health, and environment management system through holding training workshops Establishment of safety, health, environment system of the school target population for change and development in methods of training and attitudes toward the safety issues. Then they established the Education Center of Ready Children at School (KAM) in collaboration with the Passive Defense Center and the Crisis Management of Qom Municipality as well as opinions of experts on children and young adults. They studied the attitude change of the students who visited the center in the research [11].

Mostafavi Darani (2013) researched the impact of training on the primary school principals' knowledge and attitude of Borkhar County, Isfahan Province, Iran about the establishment of health, safety, and environment management system. In this quasi-experimental research, they chose 46 primary school principals as the study population and held a 2-day workshop for them and by using a researcher-made questionnaire, measured their level of knowledge and attitude by a pretest/posttest method. Their findings showed that the average number in the knowledge questionnaire about three subjects of safety, systemic, and environmental health increased af- ter the intervention. In other words, it reached from the good level to a very good level and finally, they concluded that the establishment of health safety and environment management system in an organization would affect the health of its staff and a school as an organization needs such a system, too [14].

\section{Discussion}

The purpose of the research was the review of the conducted studies on crisis management at Iranian schools. The number of studies that had been considered crisis management at Iranian schools was very limited. Four studies were examined that only one of them was an interventional study. The used tool for the studies was questionnaires. The results of Mehraeen Nazdik study [8] showed that the emergency programs had the most and the emergency operations had the least importance among the preparedness aspects. Furthermore, among the schools, $6.9 \%$ had very high preparedness, $32.7 \%$ high preparedness, $29.7 \%$ average prepared- 
ness, $22.8 \%$ low preparedness, and $7.9 \%$ very low preparedness for the earthquake risk. As the results of the study showed that the preparedness of the primary high school of Shiraz is lower than the desirable level and this preparedness rate regarding the earthquake risk is not favorable at all.

It is worth mentioning that from the health and safety point of view, the state of school buildings and equipment should be examined with respect to safety, construction, structure, and so on. We can use the relevant experts' ideas in this regard and the provided checklists for the safety of public places such as schools and also the preparedness of their infrastructures [15]. The results of Nezhadshokouhi study also showed that the most important effective factors of the preparedness for confrontation with the crisis at schools are taking safety precautions, considering primary standards, and establishing relevant committees. Therefore, the guidelines of regular inspections of educational centers with respect to safety equipment against fire and the other dangerous factors in the environment, especially at schools should take into account.

In Shirzad Kebria research [10], the results also showed that the internal school components, including physical, preventive, and interventional aspects were desirable and sub-components of education and services of health were in very poor condition. However, the internal school components influenced the external ones except for the education and services of the health aspect in which the influence was not seen. To justify this finding, we can say that in a school the provisions of safety measures and emergency conditions should be managed to the best to gain maximum safety.

Again, the results of Pourahmadi research showed that if the educational programs of crisis management at schools were followed by necessary continuation and dynamism and supported by the family's encouragement, significant changes would take place in students' awareness level and their performance at the time of the earthquake. In other words, we can say that the officials' awareness of health management is the most important element in promoting and maintaining the environmental health of the schools and the safety of the students [14].

In this regard, the written guidelines at schools on the training of individuals, especially children to get ready for emergencies can be used. Also, the staff who have been trained for first aid and resuscitation can be employed to raise the people's knowledge and attitude [16-18]. On the one hand, the findings of these studies showed that the research on crisis management at the Iranian schools was very poor and most of them emphasized that students, teachers, and principals should be trained for crisis management and confrontation with it. In addition, it is necessary to evaluate the professional competence of principals in crisis management [19]. It is recommended that we take significant steps in elevating the confrontation and intervention level of crisis through the evaluation and improvement of safety cultural level. Table 2 demonstrates all suggestions of the article. [20].

\section{Conclusion}

Generally speaking, crisis is a concept that dates back to a long time ago. However, the concept has developed throughout the world both in the developed and developing countries in recent decades. Some countries as the pioneers of this development have gained valuable experiences in this area and most of the other countries are trying to solve the existing problems and obstacles in the field. On the other hand, regarding the crucial role of the human in the sustainable development, we can say that the serious attention to and carefully planning for providing a healthy environment at schools both from physical and psychological views are the most important tasks of education and health systems of the government which will be impossible unless through the participation of the relevant institutions. That is because implementing the model of healthy schools through increasing the authorities' awareness and knowledge about crisis management has a key role in promoting and maintaining the environment health of schools and the safety of students.

This research like most of the other studies was subjected to some limitations that the researchers tried to resolve them. One of the limitations of this study was the inadequate studies in the field because the topic of crisis management is a new one in our country that its main conditions for research have not been provided yet. Moreover, it is suggested that the crisis management and the studies on the reaction to the emergencies be considered more seriously through practical maneuver at schools. Furthermore, it is better to consider the relevant measures of escaping and controlling the environmental dangers at schools, the maneuvers of school evacuation in the emergencies, the easy availability of the first aid, the parents' training about accidents, the students' education to consider safety regulation and prevent the dangerous factors.

Besides, it is suggested that the school authorities and officials of the Ministry of Education check the state of schools safety in some aspects (including location, the 
state of gas piping, heaters, radiators, and fire extinguishing facilities) and match them to the standards as far as possible. Besides, the collaboration of the relevant departments and organizations such as the Ministry of Education, the Ministry of Health, Treatment and Medical Treatment and the Crisis Management Center of Iran is one of the main reasons of the success in the improvement of the safety level and the crisis management of schools. It is hoped that with active collaboration and participation of the relevant officials, the proper conditions be created for conducting such applied research studies in different educational levels and observe the continuous promotion of the health and safety of students and the future makers of the society.

\section{Ethical Considerations}

\section{Compliance with ethical guidelines}

All ethical principles are considered in this article.

Funding

This research did not receive any grant from funding agencies in the public, commercial, or non-profit sectors.

Authors' contributions

All authors contributed in preparing this article.

\section{Conflict of interest}

The authors declared no conflict of interest.

\section{References}

[1] Kamali Y., Mirzai J. [Comparison of Crisis Management Structure in Iran, Japan, India and Turkey (Persian)]. Strategic Studies of Public Policy. 2018; 7(25): 245-89. http://sspp.iranjournals.ir/article_29735.html

[2] Poursadeqiyan M, Arefi MF. Health, safety, and environmental status of Iranian school: A systematic review. J Edu Health Promot 2020; 10:00.

[3] Mehraein NZ, Kazemi M. The study of junior high schools'earthquake preparedness in shiraz city. Scientific Journal Of Rescue And Relief. 2017; 8(1):92-104. https:// www.sid.ir/en/journal/ViewPaper.aspx?id=537763

[4] Taghvae M, Rahmani N. [An Analysis of the Status of Isfahan Office Buildings for Urban Crisis Planning and Management (Persian)]. Urban Planning and Research Journal. 2017; 8(30):101-20. http://jupm.miau.ac.ir/article_2501.html
[5] Hosseini SY, Damnabi AA. THE impact of strategic management on the quality of crisis management case study: railway transportation industry. Emergency Management. 2013; 1(2):7786. https:/ / www.sid.ir/en/journal/ViewPaper.aspx?ID=360239

[6] Rahimi E. [Studying the importance and priority dimensions in crisis management from the employees' view (Persian)]. Journal of Tehran Disaster Management and Mitigation Organization (TDMMO). 2018; 8(1):54-65. http://dpmk.ir/article-1-173-en.html

[7] Kalvir R, HJ. [Comparison of school yearnings and academic burnout in high school students (Persian)]. School Psychology. 2016; 4(4):75-60. http://jsp.uma.ac.ir/article_400.html

[8] Vosoughi M, Dargahi A, Teymouri P. Environmental health and safety assessment of schools in khalkhal city using crisis management approach. Health in Emergencies \& Disasters Quarterly. 2020; 5(2):5-5. http://hdq.uswr.ac.ir/article-1-226-en.html

[9] Hadavandi M, Hadavandi F. Evaluation the effectiveness of crisis management workshop training kerman province-2009. Scientific Journal Of Rescue And Relief. 2010; 2(1):17-32. https://www.sid.ir/en/Journal/ViewPaper.aspx?ID=200163

[10] Shirzad Kebria B. [Investigating the dimensions and components of crisis management to provide appropriate solution for high schools in Tehran (Persian)]. Journal of Educational Administration Research. 2013; 16(4):85-118.

[11] Borzoi Khah Foumani M, Iraq AS, Barzegar N. Investigating the change in the attitude of primary school students in Qom towards safety and crisis management issues in the educational center for ready-made children in school (com). The first international conference and the fourth national conference on fire and urban safety. 25 February 2018; Tehran, Iran.

[12] Pourahmadi Sh, Taqi E, Ardeshir A, Yarali N. Evaluating the effectiveness of school crisis management training courses, International Center of Academic Communication (ICOAC), University of Szczecin. 11-12 Devember 2014; Szczecin, Poland.

[13] Nejadshokohi F, Nji Azimi Z, Jameh Kurdkandi F. Comprehensive, Identifying and Prioritizing Factors Affecting Preparedness for School Crisis Using FAHP. Paper presented at: International Center of Academic Communication (ICOAC), University of Szczecin. 11-12 Devember 2014; Szczecin, Poland.

[14] Mostafawi Darani F, Larijani M, Saeedi M. Investigating the effect of education on the knowledge and attitude of primary school principals in Borkhar city regarding the establishment of health and environmental safety management system. Journal of Health System Research. 2014; 9(14):188999. http://hsr.mui.ac.ir/article-1-576-fa.html

[15] Dargahi A, Farrokhi M, Poursadeghiyan M, Ahagh M M $\mathrm{H}$, Karami A. Evaluation of functional preparedness and non structural safety of different health units of kermanshah university of medical sciences in coping with natural disasters. Health in Emergencies \& Disasters Quarterly. 2017; 2(4):201-6 [DOI:10.29252/nrip.hdq.2.4.201]

[16] Dargahi A, Bagheri S, Poursadeghiyan M, Hosseini Ahagh MM, Farrokhi M. Knowledge and attitudes of students in khalkhal medical sciences faculty on health actions in emergencies. Health in Emergencies \& Disasters Quarterly. 2017; 3(1):51-6. http://hdq.uswr.ac.ir/article-1-174-en.html

[17] Moslemie Aqily MM, Ziaddiny H, Taslimy M, Sangalajy A. Establishment and maintenance. ${ }^{\text {th }}$ Ed.Tehran: Movaffagh; 2009 . 
[18] Mokhtari S, Hosseini Goushe S N, Hosseini Fouladi S, Ivanbagha R, Hosseini Ahagh M M, Khammar A et al . Health, Safety, and Environmental Status of the Urban Parks in Iran: A Systematic Review. Health in Emergencies \& Disasters Quarterly. 2019; 4(4):179-84 [DOI:10.32598/hdq.4.4.179]

[19] Amani S, Tahmasbi S, Baneshi A, Poursadeghiyan M, Karimzadeh M. Factors Affecting Professional Competency of Iranian Preschool Administrators Based on Crisis Management Approach. Health in Emergencies \& Disasters Quarterly. 2018; 3(4):185-90 [DOI:10.32598/hdq.3.4.185]

[20] Khammar A, Poursadeghiyan M, Marioryad H, Nabi Amjad R, Alimohammadi M, Khandan M.Patient Safety Climate and Its Affecting Factors Among Rehabilitation Health Care Staff of Hospitals and Rehabilitation Centers in Iran-Tehran. Iranian Rehabilitation Journal. 2019; 17(1):39-48 [DOI:10.32598/irj.17.1.39] 